\title{
The Electoral College and Its Winner Take All System: An Outdated Machine in Modern American Democracy
}

Dr. Ferdinand Kpohoué*

Department of English Studies, Faculty of Letters, languages, Arts and Communication (F.LL.A.C.), University of Abomey- Calavi, (UAC), Benin

DOI: $10.36348 /$ sijll.2020.v03i12.004

| Received: 14.12.2020 | Accepted: 22.12.2020 | Published: 30.12 .2020

*Corresponding author: Dr. Ferdinand Kpohoué

\section{Abstract}

American voters elect the President and Vice President of the United States of America indirectly, through an arrangement known as the Electoral College system. The U.S. Constitution, in Article II, Section 1, Clause 2, as amended by the 12th Amendment in 1803, together with a series of implementing federal statutes, provides the broad framework through which electors are appointed and by which they cast votes for the President and Vice President. However, the Constitution says nothing about how the states should allot their electoral votes. The winner- take-all was the choice of the majority of the States. Presently, 48 states and the District of Columbia (Maine and Nebraska are the exceptions, having adopted the district system) have adopted the winner-take-all method of allocating electors. Under this method, the slate of electors, representing the presidential and vice presidential ticket that wins a plurality of votes in a state is elected on Election Day in November, and later meets in mid-December as the Electoral College to cast all of the state's electoral ballots for the winning presidential and vice presidential candidates. This electoral system has proved undemocratic in modern time. The objective of this paper is to shed light on the limits of the American presidential electoral system which is no more in accordance with the ideals of the democracy today. Through historicism and Marxism theories, investigations have shown that some candidates can get a majority of the popular votes but fail under the winner- take-all conundrum. More importantly, the system has generated a dangerous geographical separation with red and blue territories in the same United States. The compromises and ideals of 1787 constitutional convention are rather outmoded for the 21 st century democracy.

Keywords: Electoral College, winner- take-all, constitution, vote, presidential election.

Copyright () 2020 The Author(s): This is an open-access article distributed under the terms of the Creative Commons Attribution 4.0 International License (CC BY-NC 4.0) which permits unrestricted use, distribution, and reproduction in any medium for non-commercial use provided the original author and source are credited.

\section{INTRODUCTION}

The presidential election of 2000 was a pivotal moment in U.S. history, as the election results in a statistical tie between Democrat Al Gore and Republican George Bush. In the national popular vote, Gore received 48.4 percent while Bush received 47.9, losing by over 540,000 votes. U.S. presidents, however, are chosen by the Electoral College. Gore won over 500,000 more votes nationwide than George W. Bush however he failed. George W. Bush won the Electoral College and became president.

During the 2016 presidential election, Clinton won the popular vote with $65,853,516$ votes (48.5 percent) to Trump's $62,984,825$ (46.4 percent). However, Trump won the Electoral College, scoring 304 votes to Clinton's 227. In a modern democratic system, it is a paradox. In fact, the paradox is due to the tool used to elect the president: the Electoral College and especially the winner take all machine. The winner take all is the system by which the presidential candidate who wins a plurality of a state's popular votes wins all of its electoral votes. The choice of the Electoral College by the 1787 constitutional convention was motivated by the desire of the Founding Fathers to remove the choice of the President from the hands of popular majorities and to place the responsibility in the hands of a select body of wise, outstanding, and virtuous citizens. According to The Right to Vote: the Contested History of Democracy in the United States by Alexander Keyssar, two reasons motivated this choice: "The first was that men who possessed property (especially "real property," i.e., land and buildings) had a unique "stake in society" - meaning that they were committed members of (or shareholders in) the community and that they had a personal interest in the policies of the state, especially taxation. The second was that property owners alone possessed sufficient independence to warrant their having a voice in governance." (Keyssar, 2000:5) It is a way to avoid the election of wacky candidates as presidents of the USA. The article instituting the Electoral College has left 
each state free to choose its method of allocating electors. Except Maine and Nebraska, all the 48 other states are using the winner take all mode. The question is to know if it is still a democracy when the winner of the popular vote fails and the candidate that wins is the one chosen by the Electoral College with less votes.

The objective of this paper is to investigate the Electoral College and the Winner Take All conundrum in order to find out some modern and democratic system likely to ensure a normal representation of the American citizens. Historicism, the idea of attributing significance to elements of space and time, such as historical period, geographical place, and local culture; and Marxism have contributed to show the limits of the Electoral College with its Winner Take All instrument. In fact, the presidential electoral system in America is out-of-date in modern democracy. The $18^{\text {th }}$ century America is different from today's America: women, blacks and other minorities are full citizens and vote today. The fear of tyranny present after the war of independence (1775-1783) disappeared. "No taxation without representation" was one of the motives that lead to revolution. But through the Electoral College and the winner take all, the elected president is no more representing citizens, he rather represents states. The notion of democracy used by the Founding Fathers is not the same today. A suitable and modern solution is necessary for the American Constitution to value the vote of the American citizens in the $21^{\text {st }}$ century.

\section{History of Voting in America}

The American democracy is referred to as a very old one. After the ratification of New Hampshire on June 21, 1788, the ninth state to ratify it, the American Constitution became the supreme law putting an end to the Articles of Confederation. Catherine Drinker Bowen refers to the event in terms of "Miracle at Philadelphia: The Story of the Constitutional Convention" as the title of her book published in 1966 to give an account of the Constitutional Convention. However the so-called 'miracle' did not guarantee all the rights for a good democracy. In The Contested History of Democracy in the United States, Alexander Keyssar declares:

At its birth, the United States was not a democratic nation - far from it. The very word democracy had pejorative overtones, summoning up images of disorder, government by the unfit, even mob rule. In practice, moreover, relatively few of the new nation's inhabitants were able to participate in elections: among the excluded were most African Americans, Native Americans, women, men who had not attained their majority, and adult white males who did not own land. Only a small fraction of the population cast ballots in the elections that elevated George Washington and John Adams to the august office of the presidency [1].

Land possession, according to Keyssar, is motivated by two main reason: "The first was that men who possessed property (especially "real property," i.e., land and buildings) had a unique "stake in society"meaning that they were committed members of (or shareholders in) the community and that they had a personal interest in the policies of the state, especially taxation. The second was that property owners alone possessed sufficient independence to warrant their having a voice in governance [1].

Up to 1776 when the Declaration of independence was issued, voting was controlled by individual state legislatures. Only white men age 21 and older who own land could vote. In 1868, The 14th Amendment to the U.S. Constitution grants full citizenship rights, including voting rights, to all men born or naturalized in the United States. So far blacks were not given the right to vote though free. In 1870, the 15th Amendment to the U.S. Constitution eliminated racial barriers to voting; however, many states continued practicing voter discrimination. Poll taxes, literacy tests, fraud, and intimidation still prevented many from voting. Native Americans were still denied the right to vote. Women too were prohibited from voting, because they were thought to be dependent on adult men. They were thought to be unfit for the worldly experiences necessary for engagement in politics. These ideas were thought to be democratic in the American $18^{\text {th }}$ century. In 1920 , the $19^{\text {th }}$ Amendment to the U.S. Constitution was ratified, giving women the right to vote nationwide. The poll tax, a requirement to pay a certain sum of money in order to vote, which kept poor people from the polls, was repealed in 1923 by Washington State voters when they passed Initiative 40. Poll taxes were used in many states as a way to discriminate against certain voters. The Indian Citizenship Act of 1924 has granted Native Americans citizenship and voting rights. As for the federal Civil Rights Act passed in 1964, all men and women age 21 and older, regardless of race, religion, or education have the right to vote. The 24th Amendment to the U.S. Constitution was ratified on January 23, 1964 to eliminate poll taxes nationwide. In 1965, the federal Voting Rights Act has suspended literacy tests. In fact, the literacy test is a requirement that someone could prove the ability to read before casting a vote. In practice, literacy tests were ruses to keep poor people and minorities from the polls. Registration and voting rights are now federally enforced. The voting age which was 21 was reduced in 1971 with the $26^{\text {th }}$ Amendment to the U.S. Constitution lowering it to 18. In 1975, the federal Voting Rights Act was renewed, permanently banning literacy tests nationwide. Section 203 was added, requiring translated voting materials in areas with large numbers of citizens with limited English skills. In 1984, the federal Voting Accessibility for the Elderly and Handicapped Act requires polling places to be accessible to people with disabilities. So, from amendment to amendment, the American democratic process has worked to bring citizens closer to the polling box. Nearly 200 years are necessary to achieve 
this. However, some additional steps are still indispensable to reach the level of a modern democracy in order to put citizens, not states, at the very center of the process. "We the people of the United States", begins the preamble of the U.S. Constitution. But so far, people's votes cannot elect the U.S. president; the Electoral College has the last words. In order to appreciate it righteously, it seems important to go back to see the contexts that generated this discriminating Electoral College so as to see its forces and more specifically its weaknesses.

\section{Genesis of the Electoral College}

The Electoral College is one of the outcomes of the Constitutional Convention which is the gathering of delegates from 12 states (all but Rhode Island) that met in Philadelphia from May 25 to September 17, 1787, who wrote the American Constitution.

The delegates who gathered in Philadelphia in late May 1787 shared a common belief that what they were about to undertake, the drafting of a new constitution for the nation, was of historic importance. Riding on their shoulders rested the future of their country and the destiny of the world. Failure meant chaos and perhaps the return of oppressive, corrupt, and authoritarian government serving the privileged and oppressing the masses. They agreed that good government needed to protect liberty, property, and individual rights, although exactly what these terms meant remained open for debate. Influenced by their deep reading of European Enlightenment philosophy, of British philosophers John Locke and David Hume, French thinkers Montesquieu and Jean-Jacques Rousseau, and classical Greek and Roman authors, the Philadelphia delegates were well versed in republican theory.

By May 25, 1787, delegates from seven states (a majority of the thirteen) arrived at Philadelphia in response to Congress's call. Adopting a rule of secrecy to screen out political pressures and to make it easier for delegates to change their minds as the arguments developed, they met in the same building and room where the Continental Congress had debated and approved the Declaration of Independence. Within a few days, the number of states in attendance was up to 11. New Hampshire's delegates did not arrive until late July; Rhode Island never sent delegates. Altogether, 55 men attended at least some portion of the Constitutional Convention; 42 were present at the end, September 17; and 39 signed the document.

The framers of the Constitution were also politicians with wide practical experience since many had served as representatives in colonial assemblies or state legislatures and in Congress following the revolution. Eight were signers of the Declaration, 9 were or had been governor of a state, and 36 had served in the Continental Congress or the Congress under the
Articles of Confederation. More than half the delegates had served in the Continental Army or state militia during the Revolutionary War, most as officers. Many had also served in their state legislatures or in other high-level government positions. Some had been intimately involved in drafting their own states' constitutions. The delegates who were most important to the actual drafting of the Constitution were, instead, James Madison of Virginia, just 36 years old and a leader in the movement to strengthen the national government (and the delegate who took the most extensive notes on the debates); James Wilson, an eminent expert on the law who had come to the colonies in 1763 from Scotland and settled in Pennsylvania; and Gouverneur Morris, a Pennsylvanian who had relocated from New York, where he had helped to draft that state's constitution in 1777. Some prominent political figures, however, were absent. Thomas Jefferson was in Paris serving as envoy to France, and John Adams was in London serving as envoy to Britain.

One of the enigmatic issue during the convention was the election of the president of the republic. Some delegates, including such leading figures as Madison, Wilson, and Morris, proposed solving this problem by having the people elect the president directly, but others raised objections to direct popular election.

In the end, the delegates solved their dilemma by having specially appointed electors to select the president for a four-year term. It was also agreed that the electors would meet within their state and vote for two persons for president, one of whom at least could not be from their state. If one person received the votes of a majority of the electors appointed, he became president. Whoever came in second became vice president. If no one received votes from a majority of the electors, or if two did but tied (this was possible because each elector cast two votes), then the House of Representatives would decide, with each state having one vote. Almost two decades later, in 1804, the states ratified the Twelfth Amendment to the Constitution, which required separate votes for president and vice president.

The Electoral College is the name later given to the method of electing presidents outlined in the Constitution of 1787 whereby electors, equal to the number of representatives and senators in each state. The Electoral College is one of America's least loved and probably least understood institutions. It consists of 538 electors, and they are the ones who actually elect the president and vice president, not the millions who cast their votes on Election Day. There is one elector for every US representative and senator, plus three for Washington, DC. This "winner take all, loser take nothing" approach is not a best alternative. In fact, The Electoral College was created by the founding fathers 
as a last-ditch compromise on how to choose the president, one of the most hotly debated questions faced by the Constitutional Congress in 1787. Some wanted Congress to choose the president, thinking that they would be best informed and would choose the most qualified candidate; others argued for direct election by the citizens as a more democratic and egalitarian method. The solution was to have state legislatures elect representatives to the Electoral College, whose members, appointed by each state in a manner determined by its legislature, would subsequently choose the president. The Founding fathers wanted to remove the choice of the President from the hands of popular majorities and to place the responsibility in the hands of a select body of wise, outstanding, and virtuous citizens.

The system worked as intended only for the two elections won by George Washington. By 1796, a nascent party system proposed competing candidacies of John Adams and Thomas Pinckney for the federalists, and Thomas Jefferson and Aaron Burr for the anti-federalists or republicans. Jefferson and Burr were thus tied for the presidency, and the election went to the House of Representatives. The Electoral College threw the nation into its first, and one of its worst, constitutional crises, as federalists and dissident republicans plotted and caballed to deny Jefferson the presidency. The House required 35 deadlocked ballots before the impasse was broken and Jefferson was elected. In Ballot Battles: the History of Disputed Elections in the United States, Edward B. Foley has reported that 'the Founders had not adequately considered the topic of presidential elections. In 1823 James Madison confessed that the adoption of the Electoral College at the Convention of 1787 "took place in the latter stage of the Session," and thus "it was not exempt from a degree of the hurrying influence produced by fatigue and impatience in all such Bodies [2]."

\section{The Winner Take All And Its Impacts On The American Presidential Elections}

The Winner Take All is the system by which the presidential candidate who wins a plurality of a state's popular votes will win all of its electoral votes. The highest vote-getter wins everything, and all the other candidates win nothing. Presently, 48 states and the District of Columbia (Maine and Nebraska are the exceptions, having adopted the district system) have adopted the winner-take-all method of allocating electors. Under this method, the slate of electors, representing the presidential and vice presidential ticket that wins a plurality of votes in a state is elected on Election Day in November, and later meets in midDecember as the Electoral College to cast all of the state's electoral ballots for the winning presidential and vice presidential candidates. The Constitution leaves the method of choosing electors to the states. By 1836, reflecting democratizing reforms, all states held popular elections of electors in statewide, not district, voting. The winner-take-all electoral system was adopted for pragmatic reasons. If a state were assured to be in one party's column, then winner-take-all made sense to the party in power; the candidate that controlled the state would gain more by winning. Once supporters of one party adopted this system in their states, supporters of the other party had to follow suit in the states they controlled or lose votes in the process. State parties ran slates of candidates, with the number of potential electors on a slate equal to the number that the state was allowed; supporters routinely voted for all of the slate, guaranteeing the desired winner-take-all result. In a parallel manner, candidates would concentrate more on that state. Again, when one such state went to a winnertake-all system, other states were pressured to do the same.

How the Electoral College Became Winner-Take-All

At the beginning, state legislatures dominated as the electoral method of choice. Between 1804 and 1820 , both statewide and state legislature systems were commonly used, with a small but steady number of states using district-based methods. After 1824, states quickly began conforming to the norm of statewide selection of electors. The election of 1824 is most famous as far as the large use of the Winner-Take-All system. It was the first election in which the majority of states used a statewide winner-take-all voting method for choosing their presidential electors. As a result, the House of Representatives gave John Quincy Adams the presidency despite his winning fewer popular and electoral votes than Andrew Jackson.

Winner-Take-All is a system that now seems like a fundamental part of the American democracy. Presidential candidates compete to win states, which is how they get votes in the Electoral College. The U.S. Constitution does not mandate that system, however. Instead, it is left up to the states to determine how they select their representatives in the Electoral College. For the first thirteen presidential elections (1789-1836), spanning the first four decades of the history of the United States, states experimented with many different electoral systems.

The shift to statewide winner-take-all was not done for idealistic reasons. Rather, it was the product of partisan pragmatism, as state leaders wanted to maximize support for their preferred candidate. Once some states made this calculation, others had to follow, to avoid hurting their side. The constitutional framers could not imagine that electors could be chosen on the basis of winner-take-all rules as it is widespread today.

The following selected dates showing the evolution of the voting system in the U.S. can be useful for a global view of the system:

- 1789: George Washington is the overwhelmingly popular choice to become the first president; just 
three states allocate electors based on the winner of the statewide popular vote.

- 1792: State legislatures emerge as the preferred method of selecting presidential electors. George Mason of Virginia defended this method at the Constitutional Convention by arguing that "It would be as unnatural to refer the choice of a proper character for a chief Magistrate to the people, as it would to refer a trial of colors to a blind man."

- 1800: Virginia, the state with the most electoral votes, switches to a statewide popular vote system. Winning candidate Thomas Jefferson said of the switch in his home state: "All agree that an election by districts would be best, if it could be general; but while 10 states choose either by their legislatures or by a general ticket, it is folly and worse than folly for the other 6 not to do it." Indeed, Jefferson would have won the 1796 election if two of his strongholds had used winnertake-all. Not wanting to lose an advantage to Virginia, Massachusetts switches to a state legislature system in response, to ensure that all its electoral votes would go to John Adams.

- 1804: The 12th amendment is ratified, requiring electors to cast a single vote for a presidential ticket rather than casting two votes for their two preferred candidates, with the top finisher becoming president and the runner-up becoming vice-president. The number of states using statewide and state legislature systems is equal for the first time.

- 1812 : the number of states using statewide models decreases and the number using state legislature systems increases, suggesting that the latter might ultimately win out. A substantial number of states continue to use a district-based model.

- 1820: an equal number of states use statewide and state legislature methods for the second time. This is the last election in which state legislatures played a dominant role. By this point, political parties have become entrenched and the electors of the Electoral College can no longer realistically claim to be independent. After the election, James Madison proposes a constitutional amendment that would require states to use the district method, writing that "The district mode was mostly, if not exclusively in view when the Constitution was framed and adopted; and was exchanged for the general ticket \& the legislative election, as the only expedient for baffling the policy of the particular States which had set the example." (Amend the Constitution to Abolish the Electoral College System, 1951: 80)

- 1824: as twice as many states used the winner-takeall statewide method. The defeated Andrew Jackson joined James Madison's pleas for a constitutional amendment requiring a uniform district election system, but to no avail. In every
U.S. presidential election since, the statewide method has been predominant.

- 1836: all but one state, South Carolina, uses the winner-take-all method based on the statewide popular vote to choose its electors. South Carolina continues to have its legislature choose electors until after the Civil War.

- 1872: for the first time, every state holds a popular vote election for president, and all use the statewide winner-take-all rule. In 1876, Colorado is the last state to have its legislature choose its electors.

So far, 48 out of the 50 states refer to the Winner-Take-All method to elect the U.S. presidents.

\section{Advantages of the Winner-Take-All system}

The Founding Fathers enshrined the Electoral College in the US Constitution because they thought it was the best method to choose the president. Using electors instead of the popular vote was intended to safeguard against uninformed or uneducated voters by putting the final decision in the hands of electors most likely to possess the information necessary to make the best decision; to prevent states with larger populations from having undue influence; and to compromise between electing the president by popular vote and letting Congress choose the president. According to Alexander Hamilton, the Electoral College is if "not perfect, it is at least excellent," because it ensured "that the office of President will never fall to the lot of any man who is not in an eminent degree endowed with the requisite qualifications."(The Federalist Papers, 68, p.336) The Founders wanted to balance the will of the populace against the risk of "tyranny of the majority," in which the voices of the masses can drown out minority interests.

For the Founding Fathers, the Electoral College ensures that all parts of the country are involved in selecting the President of the United States. If the election depended solely on the popular vote, then candidates could limit campaigning to heavilypopulated areas or specific regions. To win the election, presidential candidates need electoral votes from multiple regions and therefore they build campaign platforms with a national focus, meaning that the winner will actually be serving the needs of the entire country. Without the Electoral College, groups such as Iowa farmers and Ohio factory workers would be ignored in favor of pandering to metropolitan areas with higher population densities, leaving rural areas and small towns marginalized.

The Electoral College guarantees certainty to the outcome of the presidential election. If the elections were based on popular vote, it would be possible for a candidate to receive the highest number of popular votes without actually obtaining a majority. This happened with President Nixon in 1968 and President 
Clinton in 1992, when both men won the most electoral votes while receiving just $43 \%$ of the popular vote. The existence of the Electoral College precluded calls for recounts or demands for run-off elections. The electoral process can also create a larger mandate to give the president more credibility; for example, President Obama received $51.3 \%$ of the popular vote in 2012 but $61.7 \%$ of the electoral votes. In 231 years (1789-2020), the winner of the popular vote has lost the electoral vote only five times. This happened with the presidential elections of 1824, 1876, 1888, 2000, and 2016. This proves the Electoral College system is working.

This winner-take-all system also protects the two-party system by making it difficult for third and fourth parties to score electoral votes.

\section{Limits of the Winner-Take-All System \\ Electoral Geography: Areas of Influence}

Geography shapes elections in other ways. Different areas have distinct political cultures and traditions that affect voting patterns. Even though Connecticut is affluent, its social liberalism helps Democrats. Conversely, Mississippi is the poorest state, but its social conservatism has helped the GOP carry it in most recent presidential elections. Geography also affects voters' opinions on the issues, especially when policies may benefit one area at the expense of another. Like Mississippi, West Virginia is a poor state, but it voted Republican in the presidential elections of 2000, 2004, and 2008. Democratic candidates have associated themselves with environmental policies that have arguably burdened coal mining, a major source of jobs and income for that state. Moreover, West Virginia has many hunters, who take issue with Democratic support for gun control, and its many conservative Christians tend to agree with Republicans on social issues. In deciding where to spend campaign resources, strategists ponder these patterns. In 2008, Republicans ignored Illinois, a Democratic-leaning state that would surely vote for its native son, Barack Obama. Democrats, likewise, never made a serious effort in heavily Republican Utah. Instead, both parties focused on states that could have gone either way. Ohio and Pennsylvania became the key battlegrounds. The very consequence of such a bipolarization, according to Steven Hill in Fixing elections: the failure of America's winner take all politics is that:

The political differences associated with geographic regions are exaggerated and polarized by Winner Take All. As the red and blue USA Today map illustrates so dramatically, geography largely has become a proxy for partisanship, culture, and race-racial minorities, liberals, and progressives living in the urban areas of New Goreia, whites and conservatives in the vast rural areas of Bushlandia, with the suburbs still majoritywhite but a salad mix of partisan sympathies. Yet due to its exclusive reliance on geographic representation, Winner Take All produces distorted regional representation and political monocultures with polarizing effects on policy [3].

The electoral map is made of two separate landscapes: a red wall for republican and a blue line for democrats. 'A house divided against itself cannot stand', said Abraham Lincoln on June 16, 1858.

The reasons the Founding Fathers created the Electoral College are no longer relevant. Modern technology and political parties allows voters to get necessary information to make informed decisions in a way that could not have been foreseen by the Founding Fathers. While Alexander Hamilton in 1788 saw the electors as being "free from any sinister bias," as he said in The Federalist Papers, 68 on page 335, members of the Electoral College are now selected by the political parties and they are expected to vote along party lines regardless of their own opinions about the candidates. Just as several voting laws that limited direct democracy in the Constitution have been modified or discarded throughout history, so should the Electoral College [4].

\section{THE BATTLEGROUND STATES}

The Electoral College gives too much power to "swing states" and allows the presidential election to be decided by a handful of states. In American politics, the term swing state (or battleground state) refers to any state that could reasonably be won by either the Democratic or Republican presidential candidate by a swing in votes. These states are usually targeted by both major-party campaigns. The two main political parties can count on winning the electoral votes in certain states, such as California for the Democratic Party and Indiana for the Republican Party, without worrying about the actual popular vote totals. Because of the Electoral College, presidential candidates only need to pay attention to a limited number of states that can swing one way or the other. In 2016 Donald Trump and Hillary Clinton "have made more than $90 \%$ of their campaign stops in just eleven so-called battleground states. Of those visits, nearly two-thirds took place in the four battlegrounds with the most electoral votes: Florida, Pennsylvania, Ohio, and North Carolina." Said Hari Sreenivasan, journalist at Public Broadcasting Service (PBS) on November 6, 2016.

The Electoral College ignores the will of the people. There are over 300 million people in the United States, but just 538 people decide who will be president. In 2016, Hillary Clinton won the popular vote by more than one million votes, yet still lost the election on electoral votes. Even President Donald Trump, who benefitted from the system, stated after the 2016 election that he believes presidents should be chosen by popular vote. Just as in 2000 when George W. Bush received fewer nationwide popular votes than Al Gore, Donald Trump will serve as the President of the United 
States despite being supported by fewer Americans than his opponent.

\section{LOW PARTICIPATION RATE}

Another drawback of the system is low participation rate. In fact, National and state elections for highest offices such as president, governors, and the like also are marked by declining participation as voters fail to turn out for the two-choice tango offered as standard fare. Targeted campaigns of poll-tested sound bites aimed at swing voters, swing districts, and swing states leave all other voters on the political sidelines, their issues and concerns unaddressed, wondering if the candidates are speaking to them. Not surprisingly, certain demographics of voters, such as the poor, lowincome working class, youth, and racial minorities, are disproportionately nonparticipants in our dumbed-down elections.

\section{DISPARITIES}

The electoral college as it is now constituted, with each state casting as many electoral votes as it has senators and representatives while awarding electors to candidates on a winner-take-all basis, provides an advantage to two groups of states. It yields a modest benefit to very small states, since the Constitution provides that each state elects two senators regardless of population. This means that the ten smallest states (Rhode Island, Delaware, Connecticut, New Jersey, New Hampshire, Vermont, Massachusetts, Hawaii, Maryland, West Virginia), with 3 percent of the total voters in the 2012 presidential election, maintain voting weight in the Senate equal to the ten largest states, home to 50 percent of the voters in 2012. The small states' disproportionate share of senators guarantees them slight overrepresentation in the Electoral College as well. But the near-universal use of the unit rule method of allocating electoral votes to candidates works to the advantage of large states, especially those that are politically competitive. Candidates who win a narrow majority in California alone receive more electoral votes (55) than they would by carrying all of the fourteen smallest states plus the District of Columbia (54); they can, mathematically, carry California by one vote and not receive any votes in those fourteen states and do a bit better in the electoral college. This encourages presidential candidates to focus their campaign efforts on competitive states with large numbers of electoral votes. In fact, large states are somewhat more likely to be closely divided between the parties, while smaller states are more commonly dominated by one party or the other.

\section{SOLUTIONS}

The framers' attempt to insulate the chief executive from popular choice provides the most telling example of their failure to provide a constitutional system that would be appropriate for a democratic republic. The fate of the Electoral College illustrates three aspects of this failure. First, almost from the beginning the Electoral College wholly failed to operate as the Framers had intended. It was, swiftly subverted by the emerging democratic forces. Second, even the more democratized Electoral College retained features that could and sometimes did lead to undemocratic outcomes. Finally, the requirements laid down by the Framers for amending the constitution made it extraordinarily difficult to bring about changes that might be supported by a majority of American citizens. However, the Electoral College with the Winner take all aspect need to be fixed to make modern democracy prevail in the U.S.

Robert A. Dahl, in How democratic is the American Constitution? Published in 2001 has proposed the following solutions:

From a democratic perspective, the most desirable change would be a constitutional amendment that would replace the Electoral College with the direct election of the president by popular vote; if no candidate were to receive more than 50 percent of the popular vote, a run-off election between the top two candidates would be held shortly thereafter. A second possibility is a constitutional amendment that would maintain the Electoral College but require that a state's electoral votes be allocated to candidates in direct proportion to their share of the popular votes in the state. Finally, even without a constitutional amendment, in response to a ground swell of popular opinion, state legislatures might choose the second solution - and thus return to the district system that, as we saw, was adopted in a number of states in the earliest presidential elections [5].

Another way out of the dramatic hazard the winner take all conundrum is the adoption of proportional and semi-proportional voting systems as credible alternatives for decreasing the zero-sum game of Winner Take All politics. While proportional and semi-proportional voting systems usually are discussed in the United States in the context of racial representation, in fact they are being used by most of the established democracies in the world, even among nations with more racially homogenous populations. The reason is that these non-Winner Take All voting systems also offer significant advantages in terms of the five tent poles of a representative democracy: representation, participation, campaigns and discourse, policy, and national unity. Proportional allocation may better represent minorities spread throughout a state. The District Plan offers another way out for fair representation.

The District Plan preserves the Electoral College method of electing the President and Vice President, with each state choosing a number of electors equal to the combined total of its Senate and House of Representatives delegations. One reform would have other states adopt the district plan which could be adopted by any state, under its power to appoint 
electors in Article II, Section 1, clause 2 of the Constitution, is currently used by used in Maine since 1972 and in Nebraska since 1992. If this plan were adopted nationally, each state would have popular elections resolved by plurality rule in each congressional district, as well as a statewide popular election decided by plurality rule. The winner of the popular vote in each district would get one electoral vote, and the winner of the statewide popular vote would receive two such votes (corresponding to the electoral votes provided to each state because of its senatorial representation). Under the district plan, the presidential and vice presidential candidates winning a simple majority of the electoral votes would be elected.

This plan would increase representation by allowing minority interests that have little hope of winning at the statewide level but who are concentrated in certain geographical areas to have their preferences advanced in the Electoral College. Besides, the automatic plan seems to be the simplest alternative.

The automatic plan would amend the present system by abolishing the office of presidential elector and by allocating state electoral votes on an automatic winner-take-all basis to the candidates receiving the highest number of popular votes in a state. Most versions of the automatic plan provide some form of contingent election in Congress in the event no candidate receives a majority of electoral votes. Of the proposals to reform the Electoral College, the automatic plan would result in the least change from the present system of electing the President and the Vice President.

\section{CONCLUSION}

Elections lie at the very heart of modern democracy. They are typically the occasions when citizens become most directly engaged in the political process; they determine the identity of those who will govern, often for four years; and they significantly influence how that governing power can be exercised.

Despite various criticisms and controversies, the Electoral College system has endured since the first presidential elections in 1789. Over the past two centuries, it has evolved through the ratification of one constitutional amendment, the 12th, the passage of various federal and state laws, and changing political party practices and traditions. It has delivered the presidency to the popular and electoral vote winners in 46 out of 51 elections since it became operational in 1804 , and even in the cases in which a candidate was elected with a majority of electoral votes but a minority of popular votes, the results it has delivered have been widely, if not universally, accepted as legitimate.

Interest in changing or abolishing the Electoral College has arguably been dependent, at least in recent decades, on how accurately it has appeared to ratify the voters' choice. During periods when the system seemed to be performing well, there was relatively little impetus for reform, although, as noted earlier, there was nearly always a steady stream of proposals for change. Following close elections in 1960, 1968, and 1976, however, proposed constitutional amendments providing for direct election were actively considered in the House of Representatives and the Senate in the 91st through 96th Congresses; during these periods of heightened interest, a direct popular election amendment was approved in the House in 1969 and debated, but not approved, in the Senate in 1979. In neither of these instances, however, did the proposals achieve the momentum necessary to hurdle the difficult challenge faced by all would-be constitutional amendments: approval by two-thirds of the Members of both chambers present and voting, followed by approval in three-fourths of the states. The requirements laid down by the Framers for amending the constitution made it extraordinarily difficult to bring about changes that might be supported by a majority of American citizens

During the ensuing two decades, the Electoral College delivered substantial majorities of electoral votes to the popular vote winners in every presidential election. Once again, the system functioned as its defenders predicted, notwithstanding occasional concerns over close elections and the potential impact of independent or third party candidates, and there was little impetus for change during this period. Curiously, perhaps, the bitterly contested presidential election of 2000 failed to galvanize support for direct popular election or Electoral College reform. Anger over the election's outcome seemed more intensely directed against voting system inadequacies and failures in Florida, and by extension, nationwide, that had thrust the election results into uncertainty and contention for over a month. As noted earlier, the Help America Vote Act of 2002, which sought to remedy deficiencies in elections administration technology and procedures, owed its passage largely to these controversies. So far, the electoral college with its winner take all system still preserve features that openly violate basic democratic principles: citizens of different states would are unequally represented, and a candidate with the largest number of popular votes lose the presidency because of a failure to win a majority in the electoral college. In numerous ways, the U.S. is being impaired by the continued use of a geographic-based and two-choice political system, particularly when shaped by modern campaign techniques amid dramatically shifting racial, regional, cultural, and partisan demographics. The Electoral College with its winner take all machine should be replaced by more representative system compatible with the $21^{\text {st }}$ century features.

\section{REFERENCES}

1. Keyssar, A. (2000). The Right to Vote: the Contested History of Democracy in the United States. USA: Basic Books. 
2. Foley, E. B. (2016). Ballot Battles: the History of Disputed Elections in the United States. New York: Oxford University Press.

3. Hill, A. M. (2014). American Politics for Dummies. United Kingdom: John Wiley \& Sons, Ltd.
4. Hamilton, A., Madison, J., \& Jay, J. (2008). The Federalist Papers. New York: Oxford University Press Inc.

5. Dahl, R. A., \& Levi, M. (2009). A conversation with Robert A. Dahl. Annual Review of Political Science, 12, 1-9. 